\title{
Assessment of Antiurolithiatic Potentials of Crinum asiaticum Bulbs by in vitro and in vivo Approaches
}

\author{
Suman Sura ${ }^{1 *}$, Venkata Suresh Kumar Solleti ${ }^{2}$ \\ ${ }^{1}$ Research Scholar, Jawaharlal Nehru Technological University Anantapur, Ananthapuramu, Andhra Pradesh, INDIA. \\ 2Department of Pharmacognosy and Phytochemistry, Creative Educational Society's College of Pharmacy, Kurnool andhra Pradesh, INDIA.
}

\begin{abstract}
Objectives: To evaluate the antiurolithiatic potential of Crinum asiaticum through in vitro and in vivo methods. Materials and Methods: Ethanolic extract of Crinum asiaticum (EECA) subjected for phytochemical screening and HPTLC fingerprinting. In vitro antiurolithiatic activity of EECA was determined by Calcium Oxalate $(\mathrm{CaOx})$ crystal nucleation and aggregation assays. Acute toxicity studies were performed as per OECD 423 guidelines. For in vivo antiurolithiatic activity 36 male wistar rats divided into six groups. Group I served as control, groups II to VI are administered with $0.75 \% \mathrm{v} / \mathrm{V}$ ethylene glycol for 28 days to induce hyperoxaluria where in group II served as toxic control and group III as standard. Group IV to VI served as test and received respective doses of EECA from 15 to 28 days. After 28 days, creatinine, BUN, uric acid was estimated. Calcium, oxalate, phosphate were estimated in urine and kidney homogenate also subjected for histopathological studies. Results: Phytochemical screening revealed the presence of flavonoids, terpenoids, tannins and phenolic compounds. HPTLC fingerprinting shows the presence of 7 terpenoids and 7 flavonoids at $540 \mathrm{~nm}$ and $366 \mathrm{~nm}$ respectively after derivatization. In vitro studies
\end{abstract}

showed reduction in $\mathrm{CaOx}$ crystal aggregation and promoted nucleation after treatment with EECA. In vivo studies also showed reduction in elevated levels of serum creatinine, BUN, uric acid and levelsof calcium, oxalate and phosphate in urine and kidney homogenate as compared to control group. The results were supported by histopathological studies. Conclusion: The EECA have shown significant antiurolithiatic activity by reducing calculi.

Key words: Antiurolithiatic activity, Crinum asiaticum, CaOx crystal aggregation, $\mathrm{CaOx}$ crystal nucleation, HPTLC Fingerprinting.

Correspondence

Mr. Suman Sura,

Research Scholar, Jawaharlal Nehru Technological University Anantapur, Ananthapuramu-515002, Andhra Pradesh, India.

Phone: +919949521100

Email: kalyan.suman1985@gmail.com

DOI: 10.5530/jyp.2020.12s.51

\section{INTRODUCTION}

Crinum asiaticum (Common name: Asian poison bulb) locally known as kesaracettu, is an evergreen herb that is widely distributed throughout India along river beds and also in forest. ${ }^{1}$ It is known as spider lily, Crinum lily and poison bulb in English, naagadamani in Ayurveda, bakong in Malaysia and morabau in Papua New Guinea. The plant has various ethnomedicinal properties and is used in traditional system of medicine. The ethnomedicinal uses of the Crinum asiaticum bulbs are bitter, expectorant, laxative, carminative, anthelmintic, aphrodisiac, diuretic, urinary problems, diaphoretic, nauseant, ${ }^{1}$ analgesic and antiinflammatory, ${ }^{2}$ anti-obesity, ${ }^{3}$ emetic, ${ }^{4}$ antitumor. ${ }^{5}$

The stone formation in the urinary system, i.e. in the kidney, ureter, urinary bladder and in the urethra is known as urolithiasis. 'Urolithiasis' derived from, ouron also called urine and litho means stone. It is one a foremost disease of the urinary tract and is a basis of morbidity, formation of stone the kind of urologic disorders it is occur in roughly $12 \%$ of the global population and it is occurred $70-81 \%$ in males and in females $47-60 \%{ }^{6}$

Urolithiasis is a universal trouble, cautious no environmental, artistic or ethnic groups. Since before two decades incident of primary bladder stones has extensively reduced, but these are even now a day also reported in the developing world mostly in patients who are suffered with neurogenic bladders and benign prostatic hypertrophy. Around 80\% of the stones are composed of calcium oxalate $(\mathrm{CaOx})$ and calcium phosphate. Urinary stones may source for the hindrance, hydronephrosis, illness and gush of blood in the urinary tract system. Surgical operation, lithotripsy and local calculus disruption using high-power laser are largely used to eliminate the calculi. nevertheless, these are costly and with these procedures' recurrence is quite common. The recurrence rate without preventive treatment is approximately $10 \%$ at 1 year, $33 \%$ at 5 years and $50 \%$ at 10 years. The other therapies may also be involving thiazide diuretics and alkali-citrate are used in an endeavor to prevent repetition but scientific verification for their worth is less persuasive.

\section{MATERIALS AND METHODS}

\section{Collection of plant material}

The Crinum asiaticum plant was collected from the Tirumala hills, Chittoor district Andhra Pradesh, India and confirmed by Dr. K. Madhava Chetty, Assistant Professor, Department of Botany, Sri Venkateshwara University, Tirupati (Voucher Number: 2011, dated 08.08.2017). The whole plant was dried in shade; bulbs were separated and pulverized to get a coarse powder.

\section{Preparation of extract}

The powered material was subjected for extraction by using ethanol as solvent by soxhlation process.

\section{Preliminary phytochemical screening of extract}

Crinum asiaticum bulb extracts were subjected to phytochemical testing for identification of alkaloids, glycosides, tannins, phenols, steroids, flavonoids and terpenoids following the standard procedures. ${ }^{8}$ 


\section{HPTLC analysis of ethanolic extract of Crinum asiaticum bulbs}

The ethanolic extract of Crinum asiaticum bulbs were applied in a concentration of $2 \mu \mathrm{l}$ using CAMAG Automatic TLC sampler ${ }^{4}$ applicator on precoated aluminium sheets with silica gel $60 \mathrm{~F}_{254}$ TLC plates (Merck) of $0.2 \mathrm{~mm}$ thick, $5 \mathrm{~cm} \times 20 \mathrm{~cm}$, used as a stationary phase. The plates were developed in the mobile phase of $n$-hexane: ethyl acetate (1:1) $\mathrm{v} / \mathrm{v}$ for terpenoids and ethyl acetate: formic acid: acetic acid: water (100:11:11:26) v/v/v/v for flavonoids. ${ }^{9}$ The plates were developed in CAMAG - Twin trough glass chamber saturated with saturated pad for $20 \mathrm{~min}$, at a distance of $70 \mathrm{~mm}$. After development the plates was sprayed with Anisaldehyde sulphuric acid reagent and Natural product reagent respectively for terpenoids and flavonoids using CAMAG derivatizer. The tracks were scanned using CAMAG TLC Visualizer equipped with CAMAG software $\odot$ VisionCATS-Server-PH, version 2.5.18262.1 at a wavelength of $540 \mathrm{~nm}$ using tungsten lamp and $366 \mathrm{~nm}$ using mercury lamp and the finger print profiles were recorded for terpenoids and flavonoids respectively.

\section{Evaluation of in vitro antiurolithiatic activity}

The effect of Crinum asiaticum extracts on $\mathrm{CaOx}$ crystallization was determined by the measurement of turbidity changes due to the crystal nucleation and aggregation. The precipitation of calcium oxalate at $37^{\circ} \mathrm{C}$ and $\mathrm{pH} 6.8$ has been examined by the measurement of turbidity at $620 \mathrm{~nm}$. A spectrophotometer UV/Vis (Lab India) was used to measure the turbidity of the augmentation of calcium oxalate.

\section{Nucleation assay}

Effect of ethanolic extract of Crinum asiaticum bulbs on calcium oxalate $(\mathrm{CaOx})$ crystal formation was determined by means of nucleation assay. Individually, calcium chloride $(3 \mathrm{mM})$ and sodium oxalate $(0.5 \mathrm{mM})$ solutions were filtered three times through the pore size of $0.22 \mu \mathrm{m}$ filter, from that $950 \mu \mathrm{L}$ of calcium chloride was took and to this added $100 \mu \mathrm{L}$ of extract at different concentrations $(50 \mu \mathrm{g}-3200 \mu \mathrm{g} / \mathrm{mL})$. Then add $950 \mu \mathrm{L}$ of sodium oxalate solution for initiation of crystals. Then finally the solution was magnetically moved at $800 \mathrm{rpm}$ with a stirring bar. The temperature $37^{\circ} \mathrm{C}$ was maintained. At $620 \mathrm{~nm}$ the solution optical density has been monitored. The rate of nucleation was determined with the comparison of the induction time. (The delay ahead of the exterior of crystals that have reached a critical size then consequently become optically demonstrable) if the control with the presence of extract no need to addition of corm extracts. ${ }^{10}$

\section{Aggregation assay}

Effect of ethanolic extract of Crinum asiaticum bulbs on calcium oxalate $(\mathrm{CaOx})$ crystal aggregation was determined by means of aggregation assay. $0.8 \mathrm{mg} / \mathrm{mL}$ COM crystals were used at an ultimate concentration buffered with $0.05 \mathrm{M}$ Tris containing sodium chloride $(0.15 \mathrm{M})$ at $\mathrm{pH}$ 6.5. Those all were performed at the temperature $37^{\circ} \mathrm{C}$ in the presence and absence of the corm extract after the apprehend of stirring. The of aggregation rate was predictable as below mentioned formula, by comparing the slope of the turbidity in the sample and with that turbidity in the control. ${ }^{11}$

$$
\text { Ir }=\frac{\text { Turbidity of sample }}{\text { Turbidity of control }} \times 100
$$

Ir $=$ Percentage aggregation inhibition rate

\section{Evaluation of in vivo pharmacological studies}

Healthy wistar albino rats weighing about 150-180 g are procured from animal house, CES college of pharmacy, Kurnool. They were housed in polypropylene cages and maintained at $27 \pm 2^{\circ} \mathrm{C}$, relative humidity $65 \pm 10 \%$ under $12 \mathrm{~h}$ light/dark cycles. The animals were given standard diet manufactured by Nutrivet Life Sciences, Pune, India. The study protocol was approved by the Institutional Animal Ethics Committee (Ref. No.: IAEC/CESCOP/2017-10) constituted in accordance guidelines of the CPCSEA (Committee for the purpose of Control and Supervision of Experiments on Animals), India.

\section{Acute toxicity studies}

The acute oral toxicity study was carried out as per the OECD-423 guidelines. ${ }^{12}$ One tenth of the non-median lethal dose $\left(\mathrm{LD}_{50}\right)$ was taken as effective dose. ${ }^{13}$

\section{Antiurolithiatic activity}

\section{Ethylene glycol induced urolithiasis in wistar albino rats}

The method described by Atmani et al. ${ }^{14}$ was used for the evaluation of antiurolithiatic activity of ethanolic extract of Crinum asiaticum bulbs in albino rats. Thirty-six rats were divided into six groups each group consisting of six rats.

Group-1 served as normal control receives regular diet and potable water for 28 days

Group-2 served as disease control receives ethylene glycol $(0.75 \%)$ in drinking water for 28 days

Group-3 served as standard receives ethylene glycol (0.75\%) water for 28 days and Cystone $(750 \mathrm{mg} / \mathrm{kg})$ from 15 th day-28th day

Group-4-6 served as test groups received ethylene glycol (0.75\%) water for 28 days and ethanolic extract of Crinum asiaticum bulb at the doses of $(100 \mathrm{mg} / \mathrm{kg}, 200 \mathrm{mg} / \mathrm{kg}$ and $400 \mathrm{mg} / \mathrm{kg}$ ) respectively from 15 th day-28th day.

\section{Assessment of antiurolithiatic activity}

\section{Serum analysis}

After last dose of the drug treatment, blood was collected through retroorbital plexus under slight anaesthetic conditions. Serum was separated by centrifugation (Research Centrifuge, R-22, Remi India) at 10,000×g for $10 \mathrm{~min}$ and analyzed for creatinine, uric acid and blood urea nitrogen (BUN). Serum parameters were estimated by semi-auto analyser (Mispa Excel Chemistry analyser) with diagnostic kits of Excel Diagnostic Pvt. Ltd, Hyderabad.

\section{Urine analysis}

On the $28^{\text {th }}$ day individual animal was kept in separate metabolic cages. $24 \mathrm{hr}$ of urine sample was collected. Provide the water for rats during the urine collection, urine sample was subjected for estimation of Calcium (Calcium diagnostic Kit, Agappe Diagnostics Ltd, Kerala, India), Oxalate $^{15}$ and Phosphate. ${ }^{16}$

\section{Kidney homogenate analysis and histopathology}

At the end of the study period, the rats were euthanised by using $\mathrm{CO}_{2}$ chamber and the abdomen was cut open to remove both kidneys from each animal. Isolated kidneys were washed off extraneous tissue, rinse out in ice-cold physiological saline and used for histopathology and homogenate analysis. The left kidney was finely chopped and 20\% homogenate was prepared in Tris-Hcl buffer (0.02 mol/l, pH 7.4). Kidney homogenate was used for assaying tissue calcium, oxalate and Phosphate. The right kidney was fixed in 10\% neutral buffered formalin, treated in a series of graded alcohol and xylene, fixed in paraffin wax, partitioned 
at $5 \mu \mathrm{m}$ and stained with Hematoxylin and Eosin for examination under polarized light. The histopathological examination of slides was examined under polarized light microscope (40X) and photographed by an Olympus Digital Camera.

\section{Statistical Analysis}

All the values are articulated as mean \pm SEM. The data was statistically analyzed by using one-way ANOVA followed Dunnett's t test in GraphPad Prism 5.03 version software.

\section{RESULTS}

\section{Preliminary phytochemical screening of extract}

Phytochemical screening of the ethanolic extract of Crinum asiaticum bulbs revealed the presence of flavonoids, tannins, phenolics, steroids and terpenoids.

\section{HPTLC analysis of ethanolic extract of Crinum asiaticum bulbs}

To obtain the reproducible results with high resolution different combinations of solvents with various ratios were tested. Satisfactory results were obtained with n-hexane: ethyl acetate (1:1) v/v and ethyl acetate: formic acid: acetic acid: water (100:11:11:26) $\mathrm{v} / \mathrm{v} / \mathrm{v} / \mathrm{v}$ for terpenoids and flavonoids respectively. The $2 \mu \mathrm{l}$ of ethanolic extract of Crinum asiaticum bulbs showed the presence of 7 terpenoids, 7 flavonoids with different $\mathrm{R}_{f}$ values and $\%$ of area when scanned at 540nm (Figure 1) and $366 \mathrm{~nm}$ (Figure 2) respectively for terpenoids and flavonoids after derivatization. (Table 1)

\section{In vitro antiurolithiatic activity}

In the present study the different graded concentrations i.e. from $50 \mu \mathrm{g} / \mathrm{ml}$ to $3200 \mu \mathrm{g} / \mathrm{ml}$ of ethanolic extract of Crinum asiaticum bulbs were used for in vitro evaluation of antiurolithiatic activity. The reticence of crystal formation was directly proportional to the increase in the concentration of EECA, with maximum activity was pragmatic at $3200 \mu \mathrm{g} / \mathrm{ml}$ in $\mathrm{CaOx}$ crystal nucleation and aggregation assays (Graph 1,2).

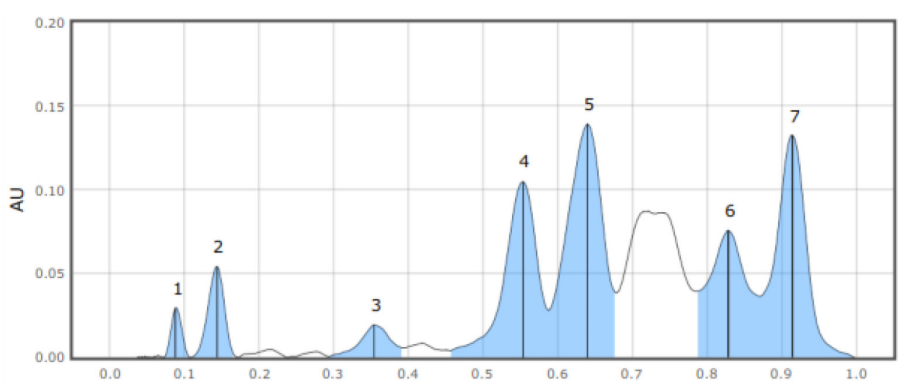

Figure 1: HPTLC chromatogram of terpenoids in $2 \mu$ l of EECA.

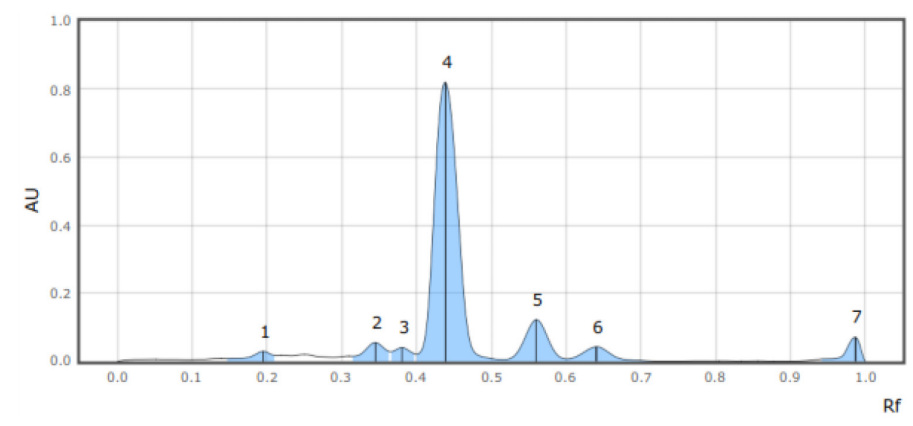

Figure 2: HPTLC chromatogram of flavonoids in $2 \mu$ l of EECA.
Table 1: HPTLC analysis of EECA.

\begin{tabular}{ccccc}
\hline \multirow{2}{*}{ Compound } & \multicolumn{2}{c}{ Terpenoids } & \multicolumn{2}{c}{ Flavonoids } \\
\cline { 2 - 5 } & $\mathbf{R}_{f}$ & $\%$ Area & $\mathbf{R}_{f}$ & $\%$ Area \\
\hline 1 & 0.070 & 1.76 & 0.160 & 10.09 \\
2 & 0.111 & 4.78 & 0.221 & 15.57 \\
3 & 0.287 & 3.59 & 0.302 & 16.78 \\
4 & 0.451 & 21.37 & 0.406 & 45.34 \\
5 & 0.592 & 28.24 & 0.519 & 6.00 \\
6 & 0.790 & 16.57 & 0.826 & 1.37 \\
7 & 0.872 & 23.70 & 0.974 & 4.85 \\
\hline
\end{tabular}

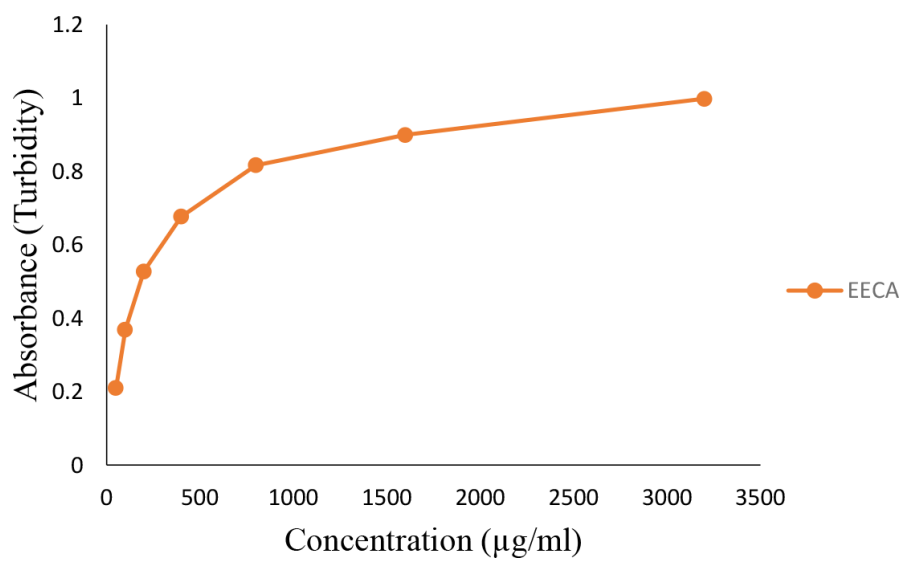

Graph 1: Effect of different concentrations of EECA on CaOx crystal nucleation.

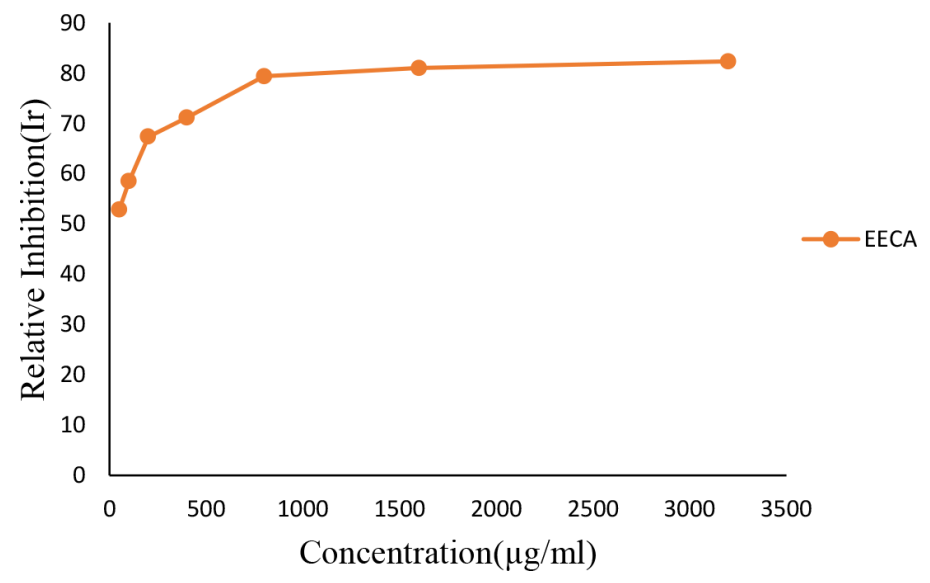

Graph 2: Effect of different concentrations of EECA on CaOx crystal aggregation.

\section{Evaluation of in vivo pharmacological studies Acute toxicity studies}

The purified and entirely dried ethanolic extract of Crinum asiaticum bulbs were subjected for the acute toxicity study to determine the lethal dose using wistar albino rats in forced environment. Acute toxicity studies were performed according to the OECD 423 guidelines. The limit test was performed with the dose of EECA (2000 mg/kg, b. w) was administered by oral route to a group of rats using oral feeding needle (22gauge). After treatment to rats were monitored for 14 days and it was observed that no changes in normal behaviour, hence it was conformed that the EECA is virtually non-toxic in normal rats and fall under the sort of GHS category 5 , according to $1 / 20^{\text {th }}$ dose $(100 \mathrm{mg} / \mathrm{kg}$. b.w), $1 / 10$ th of dose 
(200 mg/kg. b.w), 1/5th dose (400 mg/kg. b.w) from maximum safe dose was considered for further evaluation pharmacological studies.

\section{Ethylene glycol induced urolithiasis in wistar albino rats Serum analysis}

In the present study treatment with ethylene glycol $(0.75 \%)$ results in a significant $(\# \# \#<0.001)$ increase in elevated levels of $(47.58 \pm 3.27$, $2.503 \pm 0.29,4.673 \pm 0.54)$ serum BUN, creatinine and uric acid respectively when compared to normal group. These changes were restored significantly $\left({ }^{* * *} p<0.001 ; 30.26 \pm 1.85,1.10 \pm 0.19\right)$ BUN, Creatinine and $\left({ }^{\star} p<0.05 ; 2.588 \pm 0.411\right)$ uric acid in rats treated with the standard drug (cystone $750 \mathrm{mg} / \mathrm{kg}$, p.o). However, the rats treated with EECA $\left(100 \mathrm{mg} / \mathrm{kg}\right.$, p.o) pointedly decreases $\left({ }^{*} p<0.05 ; 36.06 \pm 1.63,2.497 \pm 0.76\right)$ in BUN, uric acid respectively and creatinine non significantly $((p>0.05$; $1.80 \pm 0.41)$, at the dose of EECA $(200 \mathrm{mg} / \mathrm{kg}, \mathrm{p} . \mathrm{o})$ significantly $\left({ }^{* *} p<0.01\right)$ lowers the BUN $(34.22 \pm 3.11)$ and $\left({ }^{*} p<0.05 ; 1.366 \pm 0.20,2.530 \pm 0.49\right)$ creatinine and uric acid respectively, at the dose of EECA (400mg/kg, p.o) significantly $\left({ }^{* *} p<0.001\right)$ lowers the BUN $(31.76 \pm 2.89)$ and $\left({ }^{* *} p<0.01\right.$; $1.20 \pm 0.33,1.847 \pm 0.30)$ creatinine and uric acid respectively when compared to disease control. (Table 2).

\section{Urine analysis}

The administration of ethylene glycol $(0.75 \%)$ to wistar albino rats triggers hyperoxaluria. Urinary levels of Oxalate, calcium and phosphate $(8.16 \pm 0.39, \quad 4.23 \pm 0.55,7.25 \pm 0.51)$ were unacceptably $(\# \# \#<<0.001)$ increased in the calculi-induced animals. The standard drug cystone (750mg/kg, p.o) treated group animals acceptably lowers the levels of calcium $\left({ }^{* *} p<0.001 ; 3.78 \pm 0.321\right)$, oxalate and phosphate $\left({ }^{* *} p<0.01\right.$; $2.26 \pm 0.20,4.15 \pm 0.70)$ respectively. However, treatment with EECA $\left(100 \mathrm{mg} / \mathrm{kg}\right.$, p.o) lowered the elevated level of calcium $\left({ }^{*} p<0.01\right.$; $5.66 \pm 0.74)$, oxalate $\left({ }^{\star} p<0.05 ; 2.79 \pm 0.27\right)$ and phosphate $(p>0.05$; $5.31 \pm 0.55)$, at the dose of EECA $\left({ }^{200} \mathrm{mg} / \mathrm{kg}, \mathrm{p} . \mathrm{o}\right)$ reduces the elevated levels of calcium $\left({ }^{* * *} p<0.001 ; 4.26 \pm 0.23\right)$, oxalate $\left.{ }^{*} p<0.05 ; 2.73 \pm 0.42\right)$ and phosphate $\left.{ }^{* *} p<0.01 ; 4.63 \pm 0.47\right)$, at the dose of EECA $(400 \mathrm{mg} / \mathrm{kg}$, p.o) reduces the levels of calcium and phosphate $\left({ }^{* *} p<0.001 ; 4.05 \pm 0.59\right.$, $4.05 \pm 0.370$ and oxalate $\left({ }^{* *} p<0.01 ; 2.35 \pm 0.18\right)$ in urine when associated to the disease control group (Table 3 ).

\section{Kidney Homogenate analysis}

Supernatant from the kidney homogenate was collected and subjected for evaluation of tissue calcium, oxalate and phosphate. The levels of tissue calcium, oxalate and phosphate were significantly $(\# \# ;<0.001)$

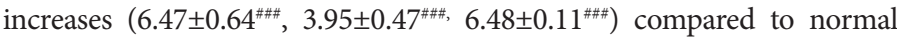
group. The animals treated with standard drug cystone $(750 \mathrm{mg} / \mathrm{kg}, \mathrm{p.o})$ significantly reduced calcium $\left({ }^{* * *} p<0.001 ; 3.58 \pm 0.85\right)$, oxalate $\left({ }^{* *} p<0.01\right.$; $2.54 \pm 0.70)$, phosphate $\left({ }^{* *} p<0.01 ; 3.89 \pm 0.70\right)$ and EECA $(100 \mathrm{mg} / \mathrm{kg}$, p.o) significantly reduces the calcium $\left({ }^{* *} p<0.01 ; 5.42 \pm 0.84\right)$, oxalate $\left({ }^{*} p<0.05 ; 3.55 \pm 0.75\right)$, phosphate $\left({ }^{*} p<0.05 ; 4.56 \pm 0.78\right), E E C A$ (200mg/ $\mathrm{kg}, \mathrm{p} . \mathrm{o})$ significantly lowers the calcium $\left({ }^{* * *} p<0.001 ; 4.95 \pm 0.73\right)$, oxalate $\left({ }^{*} p<0.05 ; 3.38 \pm 0.45\right)$ and phosphate $\left({ }^{* *} p<0.01 ; 4.05 \pm 0.50\right)$ phosphate respectively, EECA $(400 \mathrm{mg} / \mathrm{kg}$, p.o) significantly lowers the calcium $\left({ }^{* *} p<0.001 ; 4.68 \pm 0.95\right)$, oxalate $\left.{ }^{* *} p<0.01 ; 3.68 \pm 0.74\right)$ and phosphate $\left({ }^{* * *} \mathrm{p}<0.001 ; 3.78 \pm 0.77\right)$ correspondingly when compared to disease control group. (Table 4)

\section{Kidney Histopathology}

Histopathological examination of rat kidneys treated with ethylene glycol $(0.75 \% \mathrm{v} / \mathrm{v})$ revealed the presence of calcium oxalate deposits inside the renal tubules and dilation of the renal tubules along with interstitial inflammation were observed. The number of calcium oxalate deposits in the renal tubules and dilation of renal tubules of Groups III
Table 2: Effect of ethanolic extract of Crinum asiaticum (bulbs) on serum levels of BUN, Creatinine and uric acid in ethylene glycol $(0.75 \%)$ induced urolithiasis in rats.

\begin{tabular}{ccccc}
\hline S.no & Groups & $\begin{array}{c}\text { BUN } \\
(\mathrm{mg} / \mathrm{dl})\end{array}$ & $\begin{array}{c}\text { Creatinine } \\
(\mathrm{mg} / \mathrm{dl})\end{array}$ & $\begin{array}{c}\text { Uric acid } \\
(\mathrm{mg} / \mathrm{dl})\end{array}$ \\
\hline 1 & Normal & $28.28 \pm 1.74$ & $0.354 \pm 0.09$ & $1.78 \pm 0.36$ \\
\hline 2 & Disease Control & $47.58 \pm 3.27^{* * *}$ & $2.503 \pm 0.29^{* * * *}$ & $4.673 \pm 0.54^{* * *}$ \\
3 & $\begin{array}{c}\text { Standard (Cystone } \\
750 \mathrm{mg} / \mathrm{kg}, \mathrm{BW}, \mathrm{p} . \mathrm{o})\end{array}$ & $30.26 \pm 1.85^{* * *}$ & $1.10 \pm 0.19^{* * *}$ & $2.588 \pm 0.411^{*}$ \\
4 & $\begin{array}{c}\text { EECA (100 mg/kg, } \\
\text { BW, p.o) }\end{array}$ & $36.06 \pm 1.63^{*}$ & $1.80 \pm 0.41^{\text {ns }}$ & $2.497 \pm 0.76^{*}$ \\
5 & $\begin{array}{c}\text { EECA (200 mg/kg } \\
\text { BW, p.o) }\end{array}$ & $34.22 \pm 3.11^{* *}$ & $1.366 \pm 0.20^{*}$ & $2.530 \pm 0.49^{*}$ \\
6 & $\begin{array}{c}E E C A(400 \mathrm{mg} / \mathrm{kg} \\
\text { BW, p.o) }\end{array}$ & $31.76 \pm 2.89^{* * *}$ & $1.20 \pm 0.33^{* *}$ & $1.847 \pm 0.30^{* *}$ \\
\hline
\end{tabular}

All values are expressed as mean \pm S.E.M for six rats in each group.

Comparisons made between ${ }^{\# \# \# p} p<0.001,{ }^{\# \#} p<0.01, \# p<0.05$; Normal Vs Disease control,

${ }^{* * *} p<0.001,{ }^{* *} p<0.01,{ }^{*} p<0.05$; Disease control Vs Treatment: One-way ANOVA followed by Dunnett's $-t$ test.

Table 3: Effect of ethanolic extract of Crinum asiaticum (bulbs) on urinary levels of Calcium, oxalate and Phosphate in ethylene glycol $(0.75 \%)$ induced urolithiasis in rats.

\begin{tabular}{ccccc}
\hline S.no & Groups & $\begin{array}{c}\text { Calcium } \\
(\mathrm{mg} / \mathrm{dl})\end{array}$ & $\begin{array}{c}\text { Oxalate } \\
(\mathrm{mg} / \mathrm{dl})\end{array}$ & $\begin{array}{c}\text { Phosphate } \\
(\mathrm{mg} / \mathrm{dl})\end{array}$ \\
\hline 1 & Normal & $3.38 \pm 0.45$ & $1.60 \pm 0.32$ & $3.85 \pm 0.48$ \\
2 & Disease Control & $8.16 \pm 0.39^{\# * *}$ & $4.23 \pm 0.55^{\# * *}$ & $7.25 \pm 0.51^{* * *}$ \\
& $\begin{array}{c}\text { Standard (Cystone 750mg/ } \\
3\end{array}$ & $3.78 \pm 0.321^{* * *}$ & $2.26 \pm 0.20^{* *}$ & $4.15 \pm 0.70^{* *}$ \\
4 & kg,BW, p.o) & & & \\
5 & EECA (100 mg/kg, BW, p.o) & $5.66 \pm 0.74^{* *}$ & $2.79 \pm 0.27^{*}$ & $5.31 \pm 0.55 \mathrm{~ns}$ \\
6 & EECA (400 mg/kg BW, p.o) & $4.05 \pm 0.59^{* * *}$ & $2.35 \pm 0.18^{* *}$ & $4.05 \pm 0.37^{* * *}$ \\
\hline
\end{tabular}

All values are expressed as mean \pm S.E.M for six rats in each group.

Comparisons made between ${ }^{* * *} p<0.001, * \# p<0.01,{ }^{*} p<0.05$; Normal Vs Disease control,

${ }^{* * *} p<0.001,{ }^{* *} p<0.01,{ }^{*} p<0.05$; Disease control Vs Treatment: One-way ANOVA followed by Dunnett's $-t$ test.

Table 4: Effect of ethanolic extract of Crinum asiaticum (bulbs) on Kidney homogenate levels of Calcium, oxalate and Phosphate in ethylene glycol $(0.75 \%)$ induced urolithiasis in rats.

\begin{tabular}{ccccc}
\hline S.no & Groups & $\begin{array}{c}\text { Calcium } \\
(\mathrm{mg} / \mathrm{dl})\end{array}$ & $\begin{array}{c}\text { Oxalate } \\
(\mathrm{mg} / \mathrm{dl})\end{array}$ & $\begin{array}{c}\text { Phosphate } \\
(\mathrm{mg} / \mathrm{dl})\end{array}$ \\
\hline 1 & Normal & $2.68 \pm 0.85$ & $1.95 \pm 0.55$ & $2.95 \pm 0.55$ \\
2 & Disease Control & $6.47 \pm 0.64^{* * *}$ & $3.95 \pm 0.47^{* * *}$ & $6.48 \pm 0.11^{* * *}$ \\
& Standard (Cystone & $3.58 \pm 0.85^{* * *}$ & $2.54 \pm 0.70^{* *}$ & $3.89 \pm 0.70^{* *}$ \\
3 & $750 \mathrm{mg} / \mathrm{kg}, \mathrm{BW}, \mathrm{p} . \mathrm{O})$ & & & \\
4 & EECA (100 mg/kg, BW, p.o) & $5.42 \pm 0.84^{* *}$ & $3.55 \pm 0.75^{*}$ & $4.56 \pm 0.78^{*}$ \\
5 & EECA (200 mg/kg BW, p.o) & $4.95 \pm 0.73^{* * *}$ & $3.38 \pm 0.45^{*}$ & $4.05 \pm 0.50^{* *}$ \\
6 & EECA (400 mg/kg BW, p.o) & $4.68 \pm 0.95^{* * *}$ & $3.68 \pm 0.74^{* *}$ & $3.78 \pm 0.77^{* * *}$ \\
\hline
\end{tabular}

All values are expressed as mean \pm S.E.M for six rats in each group.

Comparisons made between ${ }^{\# * *} p<0.001,{ }^{* \#} p<0.01, \# p<0.05$; Normal Vs Disease control,

${ }^{* *} p<0.001,{ }^{* *} p<0.01,{ }^{*} p<0.05$; Disease control Vs Treatment: One-way ANOVA followed by Dunnett's $-t$ test. 

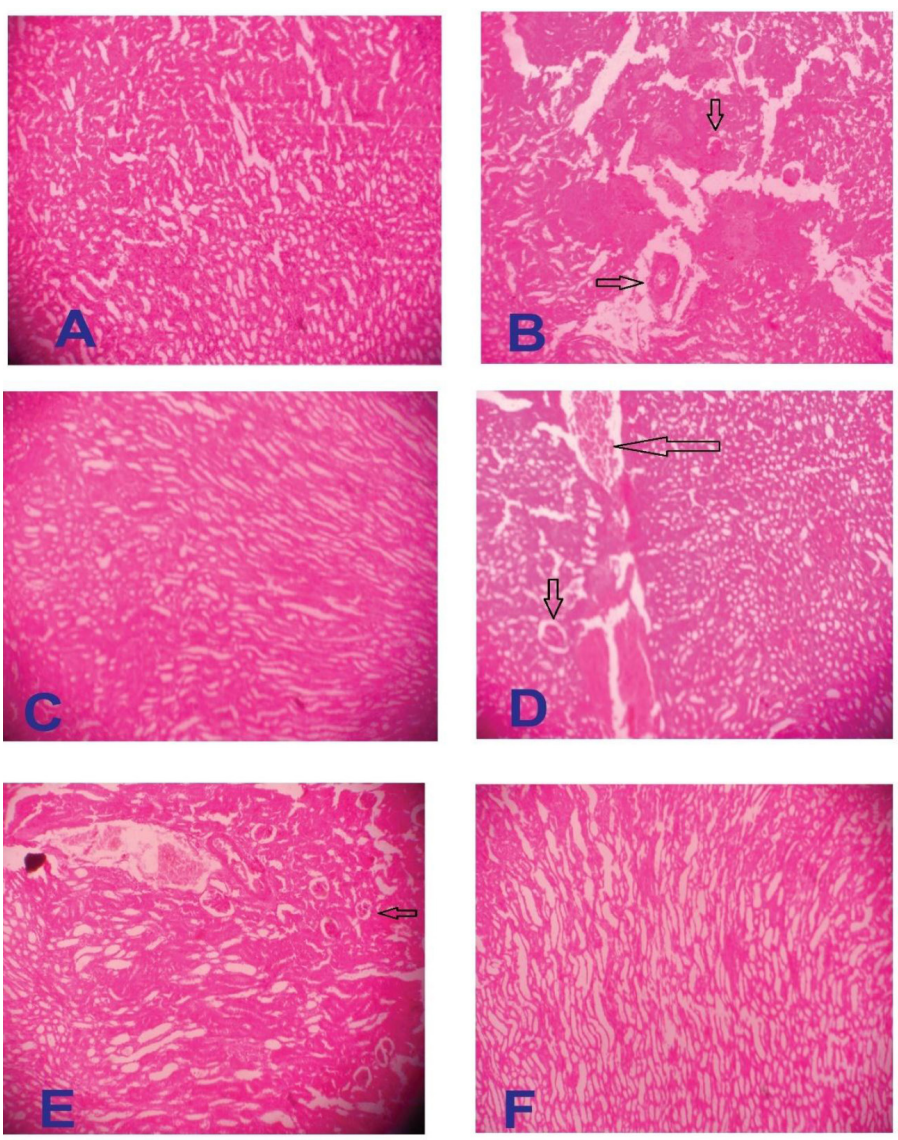

A-Normal group

B-Disease control (Ethylene glycol 0.75\% v/v)

C-Standard (Cystone $750 \mathrm{mg} / \mathrm{kg}$, bd.wt)

D-EECA $(100 \mathrm{mg} / \mathrm{kg}$, bd. wt)

E-EECA $(200 \mathrm{mg} / \mathrm{kg}$, bd. wt)

F-EECA(400mg/kg, bd. wt)

Figure 3: Histopathological view of the experimental groups. Sections show the hematoxylin and eosin (HE) stained kidney. Sections we reviewed using polarized light microscope (40X) and photographed by an Olympus Digital Camera.

(Figure 3-C) rats was significantly less than the Group II (Figure 3-B). Treatment with EECA with different doses $(100 \mathrm{mg} / \mathrm{kg}, \mathrm{BW}$, p.o, 200 mg/kg, BW, p.o, 400 mg/kg, BW, p.o) i.e., Group IV-VI (Figure 3-D-F). Significantly lowers the deposition of calcium oxalate crystal, dilation of renal tubules and interstitial inflammation were observe compared to Group-II (Figure 3-B).

\section{DISCUSSION}

$\mathrm{CaOx}$ urolithiasis is the most predominant type of all urinary stone diseases. Key magnitudes concerned in its pathological bio mineralization include crystal nucleation, growth and aggregation. Present study was aimed to discourse these key events involved in $\mathrm{CaOx}$ stone formation as a resource to investigate the efficacy of $C$. asiaticum bulbs as antiurolithiatic agent. Nucleation is an essential in the pathogenesis of $\mathrm{CaOx}$ urolithiasis. Nucleation fundamentally marks a thermodynamically driven event of phase alteration wherein dissolved substances in a supersaturated solution spontaneously crystallize ${ }^{17-19}$ Similar phase change and formation of $\mathrm{CaOx}$ crystals was witnessed while carrying out nucleation assay. The reticence of crystal formation was directly proportional to the increase in the concentration of EECA, with maximum activity was pragmatic at $3200 \mu \mathrm{g} / \mathrm{ml}$ in $\mathrm{CaOx}$ crystal nucleation.

This suggests the anticrystallization activity of EECA against $\mathrm{CaOx}$ crystallization. One possible mechanism of anticrystallization activity of EECA could be its proficiency to complex with free calcium and oxalate ions, thus blocking the formation of $\mathrm{CaOx}$ complexes, as has also been suggested for Sarghassum wightti. ${ }^{19}$

Aggregation is an important factor of crystal retention as large crystal agglomerates are the ones that produce renal tubular obstruction thereby promoting stone formation. ${ }^{19}$ EECA showed significant inhibitory effect on $\mathrm{CaOx}$ crystal aggregation.

Ethylene glycol is the most commonly used inducing agent for inducing urolithiasis in rats. The rats fed with ethylene glycol $(0.75 \% \mathrm{v} / \mathrm{v})$ results significant increase in serum levels of BUN, creatinine and uric acid and promote excessive excretion of urinary levels of calcium, oxalate and phosphate, indicate formation of calcium oxalate stones in kidneys. However, treatment with EECA, significantly lowers the elevated serum levels of BUN, creatinine and uric acid and urinary levels of calcium, oxalate and phosphate in a dose dependent manner.

Microscopic examination of rat kidney sections treated with ethylene glycol shows the presence of calcium oxalate deposits, dilatation of renal tubules along with interstitial inflammation. However, co treatment with EECA reduces the number of calcium oxalate deposits, dilatation of renal tubules and prevents the damage to renal tubules in dose dependent manner.

The phytoconstituent found in the extract such as flavonoids, tannins, phenolics, steroids and terpenoids may be responsible for the activity. In earlier literature it was reported that both flavonoids ${ }^{20}$ and terpenoids ${ }^{21}$ play a significant role in antiurolithiatic activity. Attempt also made to standardise the extract by performing finger printing of flavonoids and terpenoids by HPTLC.

\section{CONCLUSION}

In conclusion, the findings of the present study provide clear evidence that the EECA inhibits the development of calcium oxalate crystals in in vitro. The oral administration of EECA to ethylene glycol induced urolithiasis rats' results in reduction in the elevated serum levels of BUN, Creatinine and uric acid and urinary levels of calcium, oxalate and phosphate in dose dependent manner. Therefore, EECA exhibited significant anti urolithiatic activity against ethylene glycol induced urolithiasis in rats.

\section{ACKNOWLEDGEMENT}

The authors would like to acknowledge monetary support from the Principal and Management, Creative Educational Society's college of Pharmacy, NH-7, Chinnatekur, Kurnool, A.P. for providing constant support throughout the study.

\section{CONFLICT OF INTEREST}

The author claims there is no conflict of interest.

\section{ABBREVIATIONS}

CaOx: Calcium oxalate; COM: Calcium oxalate monohydrate; EECA: Ethanolic extract of Crinum asiaticum.

\section{REFERENCES}

1. Warrier PK, Nambiar VP. Indian medicinal plants: A compendium of 500 species. Orient Longman. 2006;209-11. 
2. Rahman MA, Hossain SA, Ahmed NU, Islam MS. Analgesic and anti-inflammatory effects of Crinum asiaticum leaf alcoholic extract in animal models. Afr $J$ Biotechnol. 2013;12(2):212-8.

3. Jeong YJ, Sohn EH, Jung YH, Yoon WJ, Cho YM, Kim I, et al. Anti-obesity effect of Crinum asiaticum var. japonicum baker extract in high-fat diet-induced and monogenic obese mice. Biomed Pharmacother. 2016;82:35-43.

4. Fennell CW, Staden JV. Crinum species in traditional and modern medicine. J Ethnopharmacol. 2001;78(1):15-26.

5. Min BS, Gao JJ, Nakamura N, Kim YH, Hattori M. Cytotoxic alkaloids and a flavan from the bulbs of Crinum asiaticum var. japonicum. Chem Pharm Bull. 2001;49(9):1217-9

6. Vijaya T, Kumar MS, Ramarao NV, Babu AN, Ramarao N. Urolithiasis and its causes-short review. J Phytopharmacol. 2013;2(3):1-6.

7. Takawale RV, Mali VR, Kapase CU, Bodhankar SL. Effect of Lagenaria siceraria fruit powder on sodium oxalate induced urolithiasis in Wistar rats. J Ayurveda Integr Med. 2012;3(2):75.

8. Kokate CK. Purohit AP, Gokhale SB. A Text Book of Pharmacognosy. 50th ed. Pune: Nirali Publication. 2014;A22-A7.

9. Wagner $H$, Bladt S. Plant drug analysis: A thin layer chromatography atlas. 2 nd ed. Spinger (India) Private Limited: New Delhi. 2007;195-210.

10. Hennequin C, Lalanne V, Daudon M, Lacour B, Drueke T. A new approach to studying inhibitors of calcium oxalate crystal growth. Urol Res. 1993;21(2):101-8

11. Hess B, Nakagawa YA, Coe FL. Inhibition of calcium oxalate monohydrate crystal aggregation by urine proteins. Am J Physiol Renal Physiol. 1989;257(1):F99-106.
12. OECD 423. OECD Guideline for Testing of Chemicals Acute Oral Toxicity-Acute Toxic Class Method Adopted.

13. Anupama S, Handa SS. Hepatoprotective activity of andrographolide from Andrographis paniculata against CCl4. Indian J Med Res. 1990;92:276.

14. Atmani F, Slimani Y, Mimouni M, Hacht B. Prophylaxis of calcium oxalate stones by Herniaria hirsuta on experimentally induced nephrolithiasis in rats. BJU Int. 2003;92(1):137-40.

15. Hodgkinson A, Williams AN. An improved colorimetric procedure for urine oxalate. Clin Chim Acta. 1972;36(1):127-32.

16. Fiske $\mathrm{CH}$, Subbarow $\mathrm{Y}$. The colorimetric determination of phosphorus. J Biol Chem. 1925;66(2):375-400.

17. Aggarwal KP, Narula S, Kakkar M, Tandon C. Nephrolithiasis: molecular mechanism of renal stone formation and the critical role played by modulators. Biomed Res Int. 2013;292953.

18. Basavaraj DR, Biyani CS, Browning AJ, Cartledge JJ. The role of urinary kidney stone inhibitors and promoters in the pathogenesis of calcium containing renal stones. EAU-EBU Update Series. 2007;5(3):126-36.

19. Sujatha D, Singh K, Vohra M, Kumar KV, Sunitha S. Antilithiatic activity of phlorotannin rich extract of Sarghassum wightii on calcium oxalate urolithiasisin vitro and in vivo evaluation. Int Braz J Urol. 2015;41(3):511-20.

20. Zeng $X, X i Y$, Jiang $W$. Protective roles of flavonoids and flavonoid-rich plant extracts against urolithiasis: A review. Critical Reviews in Food Science and Nutrition. 2019:59(13):2125-35.

21. Dinnimath BM, Jalalpure SS. In silico antiurolithiatic screening of Aerva lanata (L) isolated constituents. Indian J Pharm Educ Res. 2015;49(1):1-8.

Article History: Submission Date : 10-03-2020; Revised Date : 26-04-2020; Acceptance Date : 16-05-2020.

Cite this article: Sura S, Kumar SSV. Assessment of Antiurolithiatic Potentials of Crinum asiaticum Bulbs by in-vitro and in-vivo Approaches. J Young Pharm. 2020;12(2)Suppl:s76-s81. 